\title{
Assessment of Seedling Parameters and Biochemical Composition of Maize (Zea mays L.) by Soaking Process
}

\author{
Pulivarthi Vineela ${ }^{1 *}$, Yeluri Bharath Chandu ${ }^{1}$, Prashant Kumar Rai ${ }^{1}$, \\ K. Uma Maheswari ${ }^{1}$ and N. Bhavana Stella ${ }^{2}$
}

${ }^{1}$ Department of Genetics and Plant Breeding, Naini Agricultural Institute, Sam Higginbottom University of Agriculture, Technology and Sciences, Prayagraj, U. P., India

${ }^{2}$ State Institute for Management of Agriculture, Department of Agriculture, Govt. of. Uttar Pradesh, India

*Corresponding author

\section{A B S T R A C T}

\section{Keywords \\ Maize, Different pre-sowing seed treatments, Seed quality parameters, Vigour}

\section{Article Info}

Accepted:

18 November 2020

Available Online:

10 December 2020

\begin{abstract}
Maize is one of the most versatile emerging crops having wider adaptability. Globally, maize is known as "QUEEN OF CEREALS" because of its highest genetic yield potential India is the fifth largest producer of maize in the world contributing 3 percent of the global production. Hereby study was conducted in a completely randomized design with four replications in controlled conditions at Department of Genetics and Plant Breeding, SHUATS, Prayagraj (U.P) during 2018-2020, to assess the effect of pre sowing seed treatments on germination, seedling vigour, germination energy and protein in Maize. Inorganic and organic priming methods were adopted and treatments used are as $\mathrm{T}_{0}$ (Control), $\mathrm{T}_{1}-\mathrm{KNO}_{3}(2 \%), \mathrm{T}_{2^{-}} \mathrm{SA}(100 \mathrm{ppm}), \mathrm{T}_{3}-\mathrm{PEG}_{6000}(15 \%), \mathrm{T}_{4^{-}} \mathrm{CaCl}_{2}(2 \%), \mathrm{T}_{5^{-}} \mathrm{IAA}$ $(100 \mathrm{ppm}), \mathrm{T}_{6^{-}}$Neem leaf extract $(5 \%), \mathrm{T}_{7^{-}}$Mint leaf extract $(5 \%), \mathrm{T}_{8^{-}}$Moringa leaf extract(5\%), $\mathrm{T}_{9^{-}}$Curry leaf extract (5\%), $\mathrm{T}_{10^{-}}$Aloe vera leaf extract (5\%). It was found that all the treatments showed significant effect on seed quality parameters. The highest germination percentage $(\%)$, germination energy, seedling length $(\mathrm{cm})$, seedling fresh weight $(\mathrm{g})$, seedling dry weight $(\mathrm{g})$, and vigour indices were observed in treatment $\mathrm{T}_{3^{-}}$ $\mathrm{PEG}_{6000}(5 \%)$ priming for 12 hours. This study revealed that Pre-sowing seed treatment with $\mathrm{PEG}_{6000}$ enhance germinability and seedling character in Maize, its simplicity and no requirement for expensive equipment and chemical could be used as a simple method for overcoming related to a poor germination and seedling establishment. Results also indicates that priming method had little influence on protein content of maize seeds.
\end{abstract}

\section{Introduction}

Maize (Zea mays L.) is one of the world's three major crops, with rice and wheat, and is geographically the most widespread of the three. It is cultivated on over $13 \%$ of the world's croplands (Leff et al., 2004). Maize originated from Mexico and is now cultivated outside its original zone of natural selection. Maize is thermophilic plant, it is sensitive to low temperatures. It is diploid $(2 \mathrm{n}=20)$, belongs to the family Poaceae and it is widely 
cultivated in India and other parts of the world.

Maize is one of the most versatile emerging crops having wider adaptability. Globally, maize is known as "QUEEN OF CEREALS" because of its highest genetic yield potential. Maize is the only food cereal crop that can be grown in diverse seasons.

Maize grain has greater nutritional value as it contains $72 \%$ starch, $10 \%$ protein, $4.8 \%$ oil, $5.8 \%$ fiber, $3 \%$ sugar and $1.7 \%$ ash (Ghaffari et al., 2011). Maize is also used for production of ethanol, animal feed and other maize products, such as corn starch and corn syrup.

India is the fifth largest producer of maize in the world contributing 3 percent of the global production. In, India, Maize is grown in all the seasons i.e., kharif, Rabi, Summer. Of these three seasons, nearly 90 percent of the production is from Kharif season, 7-8 percent during rabi and remaining 1-2 percent in Summer season.

During the year 2017-2018, India registered a production of $27.82 \mathrm{~m}$ tones with an average productivity of $3023.9 \mathrm{~kg} / \mathrm{ha}$ from an area of $9.2 \mathrm{~m}$ ha (FAOSTAT 2018). Important maize growing states in India are Uttar Pradesh, Andhra Pradesh, Bihar, Madhya Pradesh, Maharashtra, Karnataka, Punjab, Rajasthan and West Bengal. Whereas production of maize in Uttar Pradesh occupies an area of 0.9 million hectares with an average productivity of 1.70 tones/ha and production of 1.10 million tones (Indian Institute of Maize Research-Annual Report, 2016).

Quality seed is the pre requisite for any crop improvement program. It ensures good germination, rapid emergence, vigorous growth and increased yields. Quality seeds have the ability to use the inputs such as irrigation, fertilizers, and nutrients efficiently (Mirza Hasanuzzaman, 2015).

Seed priming is a useful treatment, applied prior to planting, which partially hydrates the seeds to point of germination process initiation, followed by drying which prevents radicle emergence.

Seed can be primed by either uncontrolled hydration- hydro priming (Casenave and Tosselli, 2007; Ghassemi- Golezani et al., 2010) or controlled hydration methods which include osmotic priming, hormonal priming and solid matrix priming.

Seed enhancements aims to improve seed germination and seedling growth, encompasses many techniques performed on seed after harvest and before sowing (Copeland and McDonald, 1995 and Taylor et al., 1998).

A simple, low-cost, low-risk technology called 'on farm seed priming has been shown to improve emergence, seedling vigor and yield in a range of crops, including legumes (Harris et al., 1999; Musa et al2001 and Kumar et al., 2002).

Priming of seeds has shown to have beneficial effects on the germination and emergence of many species (Bradford,1986).The direct benefits of seed priming in crops include faster emergence, improved germination, uniformity, vigorous plants and higher yields.

The objective of this study was to evaluate the effect of various seed priming treatments on seedling parameters and protein content of maize.

\section{Materials and Methods}

The Research study was conducted at Seed Testing Laboratory, Department of Genetics 
and Plant Breeding, Naini Agriculture Institute, Sam Higginbottom University of Agriculture, Technology and Sciences, Prayagraj during rabi-2019 to find out "Assessment of seedling parameters and biochemical composition of Maize (zea mays L.) by soaking process". The data was collected on ten randomly selected healthy seedlings plants from each replication and different observations were recorded.

The treatments were represented as $\mathrm{T}_{0}$ (Control), $\mathrm{T}_{1^{-}}$Potassium Nitrate $\left[\mathrm{KNO}_{3}\right.$ (2\%)], $\mathrm{T}_{2^{-}}$Salicylic Acid [SA (100 ppm)], $\mathrm{T}_{3^{-}}$ Polyethylene Glycol [PEG 6000 (15\%)], $\mathrm{T}_{4-}^{-}$ Calcium Chloride $\left[\mathrm{CaCl}_{2}(2 \%)\right], \mathrm{T}_{5}-$ Indole

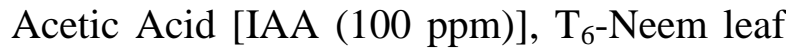
extract $(5 \%), \mathrm{T}_{7}$-Mint leaf extract $(5 \%), \mathrm{T}_{8^{-}}$ ,Moringa leaf extract (5\%), $\mathrm{T}_{9}$ - Curry leaf extract $(5 \%) \mathrm{T}_{10-}$ - Aloe vera leaf extract (5\%) and protein content was estimated by lowry's method (1951).

\section{Preparation of solutions}

The solution of $\mathrm{KNO}_{3}(2 \%)$ was prepared by dissolving $2 \mathrm{gm}$ of $\mathrm{KNO}_{3}$ in $100 \mathrm{ml}$ of distilled water each in a beaker. The solution of $\mathrm{CaCl}_{2}$ (2\%) was prepared by dissolving $2 \mathrm{gm}$ of $\mathrm{CaCl}_{2}$ in $100 \mathrm{ml}$ of distilled water in a beaker.

For the preparation of $\operatorname{IAA}(100 \mathrm{ppm}) \&$ SA(100ppm), $100 \mathrm{mg}$ of IAA and SA is dissolved in $1000 \mathrm{ml}$ of distilled water. For the preparation of botanical leaf extracts Moringa, Curry leaf, Mint, Neem leaves were collected from Horticulture Research fields, SHUATS.

These leaves were washed with water and by grinded into paste. $5 \mathrm{~g}$ of paste is mixed with $100 \mathrm{ml}$ of distilled water to make $5 \%$ solution. Aloe vera leaf extract is prepared by grinding $5 \mathrm{~g}$ of aloe vera gel with $100 \mathrm{ml}$ of distilled water.
After preparation of solutions, seeds were soaked in for a duration of $12 \mathrm{hr}$ and shade dried. These seeds were used for further laboratory studies to record observations. Preparation of solution in Lowry's method

\section{Alkaline copper reagent}

Solution A: $2 \%$ Sodium Carbonate in $0.1 \mathrm{~N}$ Sodium Hydroxide.

Solution B: $0.5 \%$ Copper Sulphate in $1 \%$ Sodium Potassium tartrate.

Solution C: Mix 50ml of solution A with $1 \mathrm{ml}$ of Solution B just prior to use.

\section{Folin - Ciocalteu reagent}

This is commercially available and has to be diluted with equal volume of water just before use.

\section{Results and Discussion}

It is evident from the present investigation that priming treatments has significant effect on quality parameters in Maize. In general, most of the treatments have increased germination and vigour parameters as compared to control (untreated seeds).

Germination percent $(97.00 \%)$, Germination Energy $(90.75 \%)$ were highest in seeds treated with $\mathrm{T}_{3}-$ Polyethylene Glycol [PEG $6000(15 \%)]$. Seedling parameters such as root length $(14.10 \mathrm{~cm})$, shoot length $(16.13 \mathrm{~cm})$, seedling length $(30.24 \mathrm{~cm})$, seedling fresh weight $(7.96 \mathrm{~g})$, seedling dry weight $(0.97 \mathrm{~g})$, Seed vigour Index-I $(2,933.31)$ and Seed vigour Index-II (94.57) were recorded highest in seeds treated with $\mathrm{T}_{3}$ - Polyethylene Glycol [PEG $6000(15 \%)$ ] followed by $\mathrm{T}_{4}-$ Calcium Chloride $\left[\mathrm{CaCl}_{2}(2 \%)\right]$ and $\mathrm{T}_{8}-$ Moringa leaf extract $(5 \%)$ however, $\mathrm{T}_{0}$-Control being the lowest (Table 1 and 2). 
Table.1 Mean performance of various priming treatments on different seed quality characters of maize seed

\begin{tabular}{|c|c|c|c|c|c|c|c|c|c|c|}
\hline S.no & Treatments & $\begin{array}{c}\text { Germination } \\
\text { percentage }\end{array}$ & $\begin{array}{c}\text { Germination } \\
\text { energy }\end{array}$ & $\begin{array}{c}\text { Root } \\
\text { length }\end{array}$ & $\begin{array}{c}\text { Shoot } \\
\text { length }\end{array}$ & $\begin{array}{c}\text { Seedling } \\
\text { length }\end{array}$ & $\begin{array}{c}\text { Seedling } \\
\text { fresh } \\
\text { Weight }\end{array}$ & $\begin{array}{c}\text { Seedling } \\
\text { Dry } \\
\text { Weight }\end{array}$ & $\begin{array}{c}\text { Seed } \\
\text { Vigour } \\
\text { Index-I }\end{array}$ & $\begin{array}{c}\text { Seed } \\
\text { vigour } \\
\text { Index-II }\end{array}$ \\
\hline $\mathbf{1}$ & $\mathbf{T}_{\mathbf{0}}$ & 88.00 & 75.25 & 10.29 & 12.17 & 22.46 & 6.31 & 0.75 & $1,974.50$ & 66.07 \\
\hline $\mathbf{2}$ & $\mathbf{T}_{\mathbf{1}}$ & 91.75 & 84.75 & 12.83 & 14.48 & 27.32 & 7.37 & 0.81 & $2,507.09$ & 74.26 \\
\hline $\mathbf{3}$ & $\mathbf{T}_{\mathbf{2}}$ & 90.75 & 83.75 & 10.82 & 12.46 & 23.28 & 6.64 & 0.77 & $2,113.06$ & 69.82 \\
\hline $\mathbf{4}$ & $\mathbf{T}_{\mathbf{3}}$ & $\mathbf{9 7 . 0 0}$ & $\mathbf{9 0 . 7 5}$ & $\mathbf{1 4 . 1 0}$ & $\mathbf{1 6 . 1 3}$ & $\mathbf{3 0 . 2 4}$ & $\mathbf{7 . 9 6}$ & $\mathbf{0 . 9 7}$ & $\mathbf{2 , 9 3 3 . 3 1}$ & $\mathbf{9 4 . 5 7}$ \\
\hline $\mathbf{5}$ & $\mathbf{T}_{\mathbf{4}}$ & 96.00 & 89.25 & 13.68 & 15.823 & 29.51 & 7.89 & 0.93 & $2,832.52$ & 90.01 \\
\hline $\mathbf{6}$ & $\mathbf{T}_{\mathbf{5}}$ & 93.75 & 86.75 & 12.86 & 14.155 & 27.09 & 7.29 & 0.76 & $2,532.38$ & 71.48 \\
\hline $\mathbf{7}$ & $\mathbf{T}_{\mathbf{6}}$ & 95.25 & 85.75 & 12.93 & 14.988 & 27.92 & 7.37 & 0.90 & $2,659.12$ & 85.98 \\
\hline $\mathbf{8}$ & $\mathbf{T}_{\mathbf{7}}$ & 93.50 & 80.75 & 12.44 & 13.24 & 25.68 & 7.07 & 0.66 & $2,400.05$ & 61.94 \\
\hline $\mathbf{9}$ & $\mathbf{T}_{\mathbf{8}}$ & 95.25 & 87.25 & 13.19 & 15.455 & 28.65 & 7.51 & 0.92 & $2,728.66$ & 87.61 \\
\hline $\mathbf{1 0}$ & $\mathbf{T}_{\mathbf{9}}$ & 89.5 & 79.75 & 11.93 & 12.90 & 24.83 & 6.72 & 0.78 & $2,220.9$ & 70.05 \\
\hline $\mathbf{1 1}$ & $\mathbf{T}_{\mathbf{1 0}}$ & 93.00 & 81.75 & 12.07 & 13.05 & 25.12 & 7.22 & 0.78 & $2,336.49$ & 72.58 \\
\hline $\mathbf{G r a n d} \mathbf{m e a n}$ & 93.06 & 84.15 & 14.08 & 12.47 & 26.55 & 7.21 & 0.82 & 2476.19 & 76.77 \\
\hline & $\mathbf{C . D .}$ & 2.461 & 3.48 & 1.219 & 0.842 & 1.449 & 0.704 & 0.068 & 128.09 & 6.65 \\
\hline & $\mathbf{S E}(\mathbf{m})$ & 0.852 & 1.20 & 0.422 & 0.291 & 0.501 & 0.244 & 0.023 & 44.32 & 2.30 \\
\hline & SE(d) & 1.204 & 1.70 & 0.596 & 0.412 & 0.709 & 0.344 & 0.033 & 62.68 & 3.26 \\
\hline & C.V. & 1.830 & 2.86 & 6.764 & 4.140 & 3.776 & 6.752 & 5.71 & 3.58 & 6.003 \\
\hline
\end{tabular}

Table. 2 Protein content estimation

\begin{tabular}{|l|c|c|}
\hline Treatments & $\begin{array}{c}\text { O.D at 660nm } \\
(\mathbf{g} / \mathbf{1 m l})\end{array}$ & $\begin{array}{c}\text { Protein content } \\
(\%)\end{array}$ \\
\hline $\mathbf{T}_{\mathbf{0}}-$ control & $\mathbf{0 . 1 4 2}$ & 9.07 \\
\hline $\mathbf{T}_{\mathbf{3}}-\mathbf{P E G}_{6000}$ & $\mathbf{0 . 1 4 9}$ & 9.52 \\
\hline $\mathbf{T}_{\mathbf{8}}$-Moringa leaf extract & $\mathbf{0 . 1 4 3}$ & 9.14 \\
\hline
\end{tabular}

From the present investigation it is concluded that the pre-sowing treatments with osmo priming can be used for enhancement of germination and vigor of Maize. Osmo priming with $\mathrm{T}_{3}$ (Polyethylene Glycol [PEG @15\%)] was found to be suitable in all the treatments and showed superior performance on Seedling parameters of maize seeds followed by $\mathrm{T}_{4} \quad\left(\mathrm{CaCl}_{2} \quad @ 3 \%\right)$, and $\mathrm{T}_{8}$ (Moringa leaf extract @5\%) and control being the lowest. The results also indicates that priming method had little influence on protein content of maize when compared to control. The experimental observations of increase in germination and quality parameters indicate the effect of osmotic priming on physiological processes of the seeds. Polyethylene glycol is eco- friendly and economic in use and can be efficiently used for improving seed quality parameters.

\section{References}

Afzal, Hussain, Basra, S.M.A, Rehman H (2012) Priming with moringa leaf extract reduces imbibitional chilling injury in spring maize. Seed Science and Technology, 40(2), 271-276.

Ali, U. A., Tareen, S., Md. JavedAli., Ijaz, T. and Md. Naveed., (2012). Effects of Seed Priming on the Antioxidant Enzymes activity of Mungbean (Vigna 
radiata) Seedlings.Pakistan Journal of Nutrition, 11'2): 140

Bradford K.J., 1986; Manipulation of seeds water relation via osmotic priming to improve germination under stress condition. Horticulture science, 59 (2): $672-676$.

Chavan, N. G., Bhujbal, G. B. and Manjare, M. R., (2014). Effect of Seed Priming on Field Performance and Seed Yield of Soybean [Glycine $\max$ (L.)Merill] Varieties.The bioscan, 9(1): 111-114.

Dutta S K and Singh A R. (2015) Effect of priming on germination and seedling vigour of bird's eye chilli seeds collected from eastern Himalayan region of India. The Bioscan 10(1) 279-284.

FAOSTAT (2018).Food and Agricultural Organization Statistics. www.fao.org.

Farahbakhsh H. (2012). Germination and seedling growth in primed and primed seeds of fennel as affected by reduced water potential induced by $\mathrm{NaCl}$. International Research Journal of Applied and Basic Sciences 3: 737744.

Faruk T. (2015) Effects of Different Priming Treatments on Seed Germination properties, Yield Components and Grain Yield of Lentil (Lens culinaris Medik.) Notulae Botanicae Horti Agrobotanici Cluj-Napoca.43(1).

Girolamo, G.D., and Barbanti, L. (2012). Treatment conditions and biochemical processes influencing seed priming effectiveness. Italian Journal of Agronomy. 7 (2): 178-188.

International Seed Testing Association, ISTA (2011) International Rules for Seed Testing. Zurichstr. CH-8303 Bassersdorf, Switzerland.

Iqbal M.A, Cheema Z.A. and Afzal M.I (2015) Evaluation of forage soybean germination and seedling growth enhancement by seed priming techniques. American-Eurasian

Journal of Agricultural and Environmental Sciences, 15, 11981203.

Kumar and Singh R. (2013) Effect of priming on emergence \& vigour of bitter gourd. Journal of research. Punjab Agriculture University. 50(3\&4).114118.

Padmavathi S, Gunasekar J, Kamaraj A, (2017). Effect of presowing seed treatment using botanical extract on growth and yield characters in blackgram (Vigno mungo L.). Plant Archives Vol. 17 No. 2, 2017 pp. 1013-1016.

Paparella S, Araujo SS, Rossi G, Wijayasinghe $\mathrm{M}$, Carbonera $\mathrm{D}$ and Balestrazzi A. (2015). Seed priming: state of the art and new prospectives. Plant Cell Reports 34: 1281-1293.

Salah SM, Yajing G, Dongdong C, Jie L, Aamir N, QijuanH, Weimin H, Mingyu N and Sharma, A. D., Rathore, S. V. S., Kalyani Srinivasan and Tyagi, R. K., (2014). Comparison of various seed priming methods for seed germination, seedling vigour and fruit yield in okra (Abelmoschus esculentus L. Moench). Scientia Horticulturae, 165: 75-81.

Jin H. (2016). Seed priming with polyethylene glycol regulating the physiological and molecular mechanism in rice (Oryza sativa L.) under nano-ZnO stress. Scientific Reports 5: 14278.

Wajid, H. A., Alderfasi, A. A., Afzal, I., Junaid, M. B., Mahmood, A., Ahmad, A., and Tahir, M. U. (2018). Evaluating the Potential Effect of Seed Priming Techniques in Improving Germination and Root Shoot Length of Maize Seed. Cercetari Agronomice in Moldova, 51(2), 5-15.

Warkad D.P., Bhingarde, M.T., Shelar, V.R., 
and Damame, S.V. (2017) Effect of chemical stimulation on plant growth, seed yield and quality parameters of rabi sorghum [Sorghum bicolor (L.) Monech]. Trends in Biosciences, 10(1), 405-409.

Yasmeen A, Basra S.M.A, Wahid A, Nouman W and Rehman (2013) Exploring the potential of Moringa leaf extract (MLE) as a seed priming agent in improving wheat performance. Turkish
Journal of Botany, 37(3), 512-520.

Yu Tian, Bo Guan, Daowei Zhou, Junbao Yu, Guangdi Li, Yujie Lou. (2014) "Response of seed germination, seedling growth and seed yield traits to seed pre -treatment in maize (Zea mays L.)", The Scientific World Journal, Article ID 834630, https://doi.org/10.1155/2014/834630.

\section{How to cite this article:}

Pulivarthi Vineela, Yeluri Bharath Chandu, Prashant Kumar Rai, K. Uma Maheswari and Bhavana Stella, N. 2020. Assessment of Seedling Parameters and Biochemical Composition of Maize (Zea mays L.) by Soaking Process. Int.J.Curr.Microbiol.App.Sci. 9(12): 2703-2708. doi: https://doi.org/10.20546/ijcmas.2020.912.320 